\title{
Implementasi Metode Fonik dalam Pengenalan Bunyi Bahasa Inggris
}

\author{
Agus Prayogo \& Lulut Widyaningrum \\ Universitas Islam Negeri Walisongo Semarang \\ Email : agusprayogo@walisongo.ac.id
}

\begin{abstract}
Each language has a different sound system and syllable structure with varied complexity. English is a language that has complicated spellings and syllables, so it is necessary to learn the pronunciation of English words in terms of phonemes and alphabets. The difficulty for non-native English speakers is the very small vocal movement, except in a careful pronunciation. This article aims at describing the teacher empowerment program with three main designs begins with socialization, training, and guidance to teachers. The main objective of this program is to introduce ways that can be done by English teachers at schools and madrasas in the Sub-Region of Boja, Kendal regency, Central Java, in applying phonicsbased teaching method and providing guidance to the teachers during the implementation process.
\end{abstract}

Abstrak: Tiap bahasa memiliki sistem bunyi dan stuktur silabel yang berbeda dengan kerumitan yang beragam. Bahasa Inggris merupakan salah satu bahasa yang memiliki ejaan yang cukup rumit dan memiliki beberapa silabel-silabel yang sangat kompleks sehingga sangat perlu mempelajari pengucapan katakata bahasa Inggris dalam kaitan fonem daripada huruf-huruf alfabetnya. Kesulitan bagi penutur asing terhadap bahasa Inggris modern adalah pergerakan vokal yang sangat kecil, kecuali dalam pengucapan yang hati-hati. Artikel ini betujuan mendeskripsikan program pemberdayaan guru dengan tiga disain utama dimulai dengan sosialisasi, pelatihan hingga pendampingan terhadap guru. Tujuan utama program ini adalah memperkenalkan cara-cara yang bisa dilakukan oleh guru-guru bahasa Inggris di lingkungan sekolah dan madrasah di Sub Wilayah Boja, Kabupaten Kendal, Jawa Tengah, dalam mengaplikasikan pengajaran berbasis metode fonik serta memberikan pendampingan terhadap guru-guru tersebut dalam proses implementasinya.

Kata Kunci: Fonik, Penguatan, Metode. 


\section{PENDAHULUAN}

Bahasa merupakan alat untuk mengungkapkan pikiran atau perasaan dengan menggunakan simbol-simbol komunikasi yang bermacam-macam baik berupa gestur, tulisan, dan suara. Suara atau bunyi menjadi aspek utama ketika bahasa tersebut diproduksi atau diucapkan oleh manusia. Suara atau bunyi sangat menentukan arti dan makna yang ingin disampaikan oleh penuturnya. Akan tetapi, bahasa memiliki sifat arbriter yang cenderung berubah-ubah dan tidak tetap (Chaer. A.,2007). Artinya, tidak ada hubungan wajib antara lambang bahasa yang berwujud bunyi tersebut dengan konsep atau pengertian yang dimaksud oleh lambang tersebut. Hal ini terjadi pada semua bahasa tidak terkecuali bahasa Inggris.

Tiap bahasa memiliki sistem bunyi dan stuktur silabel yang berbeda dengan kerumitan yang beragam. Bahasa Inggris merupakan salah satu bahasa yang memiliki ejaan yang cukup rumit dan memiliki beberapa silabel-silabel yang sangat kompleks sehingga sangat perlu mempelajari pengucapan kata-kata bahasa Inggris dalam kaitan fonem daripada huruf-huruf alfabetnya. Kesulitan bagi penutur asing terhadap bahasa Inggris modern adalah pergerakan vokal yang sangat kecil, kecuali dalam pengucapan yang hati-hati. Karena itulah, vokal tengah dalam tiga pola triftong sulit didengar dan suara yang dihasilkan sulit dibedakan dari beberapa diftong dan vokal panjang. Salah satu kompleksitas bahasa Inggris adalah triftong (triphthong). Ia lebih sulit diucapkan dan sulit untuk dikenali. Berbeda dengan diftong yang berbunyi dua rangkap untuk satu silabel, triftong adalah luncuran satu vokal menuju vokal kedua dan ketiga, dan diucapkan secara cepat. Sebagai contoh, pengucapan kata hour kualitas vokal mirip a: yang meluncur melalui area vokal belakang bundar (salah satu simbol yang digunakan adalah $\mho$ ), kemudian diakhiri dengan vokal tengah/mid-central (ə). Simbol [avə] digunakan dalam pengucapakan hour (Roach, 1998). Mengingat bahasa Inggris merupakan bahasa asing, dibutuhkan latihan yang intensif dalam penguasaan bunyi dalam bahasa inggris agar dapat mengucapkan dan menyampaikan makna dengan tepat.

Salah satu kesulitan yang menjadi hambatan pembelajar bahasa inggris di Indonesia adalah kemampuan mengenali dan mengucapkan bunyi dengan baik. Fakta di lapangan menunjukkan banyak anak-anak hingga orang dewasa yang masih mengucapkan kata dalam bahasa Inggris seperti halnya bahasa Indonesia diucapkan. Kasus seperti anggota dewan, yang notabenya bergelar doktoral, yang salah dalam membaca kata bahasa Inggris dalam sebuah forum resmi beberapa saat yang lalu bahkan menjadi bahan lelucon di kalangan masyarakat. Ada 
beberapa faktor kenapa hal ini bisa terjadi diantaranya adalah tidak konsistennya bunyi dari bahasa Inggris itu sendiri sehingga memunculkan stigma negatif, kurangnya kesadaran dari pengguna maupun pembelajar tersebut, serta kurangnya perhatian guru terhadap pengetahuan fonik hingga kurangnya penggunaan stategi yang menekankan pada aspek tersebut dalam proses pembelajaran. Contoh inkonsistensi bisa dilihat bagaimana huruf $\mathrm{C}$ seharusnya diucapkan, kapan harus berbunyi [c], kapan harus berbunyi [s], hingga kapan huruf itu berbunyi $[\mathrm{k}]$. Hal-hal inilah yang seharusnya diperhatikan oleh para pendidik sehingga tidak terjadi kesalah yang cukup masif dikalangan masyarakat.

Salah satu cara yang bisa dilakukan adalah memberdayakan para pendidik agar mampu mengenali dan mengaplikasikan sistem fonik bahasa Inggris (English Phonics System). Fonik Bahasa Inggris lebih menekankan pada pelajaran alfabet yang diberikan terlebih dulu kepada anak-anak, mempelajari nama-nama huruf dan bunyinya. Setelah mereka mempelajari bunyi huruf mereka akan mulai merangkum beberapa huruf tertentu untuk membentuk kata-kata. Kaidah fonik memperkenalkan anak-anak pada bunyi bagi setiap huruf bukannya nama huruf tersebut. Contohnya untuk huruf A, bunyinya /a/. Untuk huruf U, bunyinya 'u'. Setelah itu, jika anak-anak sudah mengenal bunyi bagi setiap huruf, kita boleh mengajar anak untuk menggabung bunyi pula. Contohnya bunyi untuk $M$ (disebut em) dan A (disebut aa) akan menghasilkan bunyi MA. Selanjutnya, jika anak-anak sudah mampu menggabung bunyi dengan sendiri, mereka akan mampu membaca bahan bacaan apa saja yang diberikan pada mereka. Fonik ini sangat tepat karena menganut prinsip perkembangan bahasa anak. Sebenarnya anak-anak pada saat masih kecil akan mulai menyebut bunyi-bunyi tertentu pada usia 4 bulan secara individu. Ketika usia mereka mulai memasuki 8 bulan, mereka akan mulai menggabungkan suara-suara tersebut. Konsep perkembangan ini yang menjadi dasar dari sistem fonik yang akan dijadikan dalam program pengabdian melalui pelatihan dan pendampingan bagi para pengajar bahasa Inggris.

Program pemberdayaan guru ini menjadi kegiatan pengabdian masyarakat dengan tiga disain utama dimulai dengan sosialisasi, pelatihan hingga pendampingan terhadap guru. Tujuan utama program ini adalah memperkenalkan cara-cara yang bisa dilakukan oleh guru-guru bahasa Inggris di lingkungan sekolah dan madrasah di Sub Wilayah Boja, Kendal dalam mengaplikasikan pengajaran berbasis sistem fonik bahasa Inggris serta memberikan pendampingan terhadap guru-guru tersebut dalam proses implementasinya. 


\section{FONIK DALAM BAHASA INGGRIS}

Fonik secara sederhana adalah hubungan antara simbol huruf dengan suara (Serna, 2006). Fonik juga bisa diartikan dengan penerjemahan lambanglambang huruf dalam suara yang diucapkan (Phajane, 2014). Inti dari fonik terletak pada alfabet yang memiliki suara tertentu. Setiap huruf tersebut merepresentasikan suara yang berbeda-beda. Untuk menghasilkan bunyi yang mempuyai arti, setiap huruf harus dihubungkan sesuai dengan kesesuaiannya. Setiap kata dan bentuk yang tertulis tersebut harus dipelajari agar dapat digunakan untuk berkomunikasi dan memperlajari fonik ini merupakan proses berkelanjutan bagi seseorang dalam belajar.

Fonik mempunyai beberapa elemen dimana kesesuaian antara huruf dan bunyi tersaji dalam beberapa cara berbeda. Jika huruf mempunyai bentuk yang sama, suara datang dalam unit yang berbeda seperti suku kata, onsets dan rima dan fonem. Setiap suku kata terdiri dari onset, rima dan atau kombinasi keduanya. Onset adalah setiap konsonan yang disajikan sebelum vokal dalam suku kata. Misalnya, dalam kata "star" / st/ adalah awal (onset). Sebaliknya rima adalah setiap vokal dan konsonan (s) yang menyusul onset. Dalam "star" /ar/ adalah rima itu. Fonem adalah unit-unit kecil dari suara yang membentuk sebuah kata. Sementara "star" hanya terdiri dari satu suku kata, itu berisi empat fonem yang berbeda: /s/ / t/ / a / / / (www.k12reader.com).

Ada beberapa kelebihan dari metode fonik ini yaitu dapat diajarkan dengan struktur bahasa yang disesuaikan dengan kaidah linguistik dan perkembangan bahasa anak; dapat dilaksanakan sesuai dengan kerja otak anak sehingga mempunyai kesan tidak memaksa, bermakna dan kontekstual; dapat mendorong anak untuk tidak sekedar membaca namun juga mengajarkan cara menulis yang proporsional. Dengan beberapa kelebihan tersebut, metode ini memungkinkan untuk dapat diajarkan oleh siapapn dan dimanapun baik di sekolah maupun di rumah. Selain itu, metode ini telah terbukti mampu meningkatkan kemampuan siswa dalam mengenali huruf termasuk dengan siswa tuna rungu atau difabel (Wulandari, 2012).

\section{PERAN FONIK DALAM PENGAJARAN MEMBACA}

Dari detail fonik tadi, dapat kita coba untuk mengaitkan peran fonik dalam membaca. Dalam penjelasan tersebut, dapat kita ketahui bahwa phonik dan kesadaran fonemik (pemahaman bahwa kata-kata yang terdiri dari segmen kecil dari suara) sangat erat terhubung. Fonik sangat bergantung pada kesadaran pembaca akan fonem. Pembaca tidak hanya harus memahami bahwa kata-kata 
yang terdiri dari fonem (unit-unit kecil dari suara), ia juga harus tahu beberapa fonem. Meskipun kesadaran fonem primer pembaca berkembang melalui berbicara dan mendengarkan, kebanyakan anak-anak membaca dengan berbekal banyak fonem disimpan di bank pengetahuan mereka. Pengajaran fonik menghubungkan fonem ini dengan huruf yang ditulis sehingga mereka dapat mentransfer pengetahuan mereka tentang suara untuk kata yang dicetak. Inilah sebabnya mengapa pengajaran fonik merupakan komponen penting dari pendidikan membaca awal. Pengajaran fonik dianggap menjadi cara yang efektif dalam mengajarkan anak-anak membaca (NRP, 2004; Phajane, 2014).

Bagaimana peran fonik dalam membaca? Metode fonik menekankan pada keterkaitan kata dengan bunyi huruf. Pengenalan pada bunyi-bunyi huruf kemudian disusun menjadi suku kata dan kata. Pengajaran fonik merupakan pendekatan pengajaran literasi yang fokus pada hubungan antara huruf dan suara (Clark, 203). Pengenalan bunyi dengan mengaitkan huruf dan kata harus diperkenalkan sedini mungkin. Membaca dengan metode fonik memiliki tiga tahapan yang meliputi tahap merah, tahap biru, dan tahap hijau. Tahap merah berarti membaca dengan suku kata terbuka seperti pada kata mata, papa, mama. Tahap biru berarti membaca kata yang mengandung suku kata tertutup seperti pada kata motor (mo-tor) dan jendela (jen-dela). Sedangkan tahap hijau berarti membaca kata yang mengandung suku kata double vokal dan doble konsonan seperti pada kata pakai (pa-kai) dan pulau (pu-lau) untuk double vokal dan kata nyenyak (nye-nyak), bintang (bin-tang), dan struktur (struk-tur) untuk kata dengan double konsonan.

Tujuan dari pengajaran fonik adalah untuk membantu siswa supaya dapat menentukan suara dari kata-kata tertulis yang tidak dikenali secara cepat. Ketika siswa menemukan kata-kata baru dalam teks-teks, mereka dapat menggunakan unsur-unsur fonik untuk mengkodifikasi dan memahami kata-kata tersebut. Ada beberapa cara untuk menerapkan fonik dalam membaca. Fonik sintetis membangun kata-kata dari bawah ke atas. Dalam pendekatan ini pembaca mengaitkan huruf dengan fonem atau unit suara yang sesuai dan kemudian dicampur bersama-sama untuk menciptakan sebuah kata. Misalnya, jika siswa menemui kata "apel" dan tidak mengenalinya, ia akan terdengar keluar setiap segmen dari kata (/ a / / p / / 1 /) dan kemudian berbaur suara ini bersamasama untuk mengatakan seluruh kata. Fonik analitik, di sisi lain, melakukan pendekatan kata dari atas ke bawah. Sebuah kata diidentifikasi sebagai unit utuh dan kemudian koneksi surat-suara diurai keluar. Pendekatan ini sangat membantu ketika siswa datang ke kata-kata yang tidak dapat terdengar keluar (seperti "caught" dan "light") dan penguatan terhadap kata-kata sejenis. Analogi 
fonik menggunakan bagian kata-kata yang familiar untuk menemukan kata-kata baru. Ketika menerapkan analogi fonik ada kata "stun" seorang siswa dapat melihat bahwa paruh kedua kata tersebut sama dengan kata-kata familiar lainnya seperti "sun" dan "fun". Kemudian, dia dapat menerapkan pengetahuan tentang fonem ini untuk mengkodifikasi kata tersebut dengan mudah.

\section{IMPLEMENTASI PROGRAM}

Program pemberdayaan guru ini terdiri dari tiga kegiatan utama yaitu sosialisasi, pelatihan, dan pendampingan. Adapun deskripsi lengkap tiap-tiap kegiatan tersebut adalah sebagai berikut. Pertama, Sosialisasi. Kegiatan sosialisasi dalam suatu program merupakan aspek krusial yang harus dijadikan prioritas. Pada dasarnya tujuan sosialisasi adalah membangun hubungan kerja sama dengan berbagai komponen masyarakat dan lembaga yang ada. Melalui kerja sama yang erat, diharapkan masyarakat mempunyai rasa memiliki sehingga masyarakat tidak hanya menerima manfaat saja namun juga memfasilitasi mereka untuk terlibat secara lebih berarti. Pada prinsipnya, sosialisasi diharapkan dapat menyampaikan pesan pada masyarakat yang dituju atau ditargetkan. Dengan demikian perlu dipilih cara yang sesuai dengan masyrakat yang ditargetkan. Hal ini juga berlaku pada program pengabdian masyarakat berbasis pemberdayaan guru dengan menggunakan metode fonikbagi guru bahasa Inggris. Oleh karena itu, program pengabdian masyarakat harus disoialisasikan kepada seluruh sivitas akademika, masyarakat dan pemerintah terkait, serta diupayaan pengembangan pelaksanannya secar terus menerus, melalui kerjasama yang saling menguntungkan dengan pihak lain yang terkait.

Tujuan utama kegiatan sosialisasi adalah untuk memberikan gambaran (overview) tentang kegiatan pengabdian yang akan dilaksanakan. Selain itu, juga untuk meminta ijin untuk melaksanakan rangkaian kegiatan Pengabdian pada Masyarakat yang terdiri dari dua (2) kegiatan utama, yaitu dalam bentuk Pelatihan guru-guru pengampu mata pelajaran Bahasa Inggris SMP dan MTs di Sub Rayon wilayah Boja, Kendal dan dilanjutkan dengan kegiatan Pendampingan para guru tersebut. Lebih lanjut lagi, kegiatan sosialisasi ini sekaligus untuk menentukan tanggal pelaksanaan pelatihan dan rencana pendampingan.

Kegiatan sosialisasi dilaksanakan pada tanggal 20 Mei 2016 dilaksanakan di Aula SMPN 1 Boja dengan alamat Jl. Kaliwungu No. 20, Boja Kendal. Adapun target utama dari sosialisasi ini adalah untuk memudahkan masyarakat memahami pesan yang disampaikan. Kegiatan ini disampaikan langsung oleh Pengabdi sendiri, yaitu Lulut Widyaningrum, M.Pd. Pengabdi adalah dosen tetap 
yang bertugas di Jurusan Pendidikan Bahasa Inggris, Fakultas Ilmu Tarbiyah dan Keguruan (FITK) UIN Walisongo Semarang.

Kegiatan Sosialisasi pada program Pengabdian pada Masyarakat ini disampaikan pada para Kepala Sekolah dan Kepala Madrasah di Sub Rayon SMP/MTs wilayah Boja, Kendal. Terdapat 3 Kepala Sekolah SMP yaitu SMPN 1 Boja, SMPN 2 Boja, dan SMPN 3 Boja serta 2 Kepala Madrasah Tsanawiyah yaitu MTs NU 11 Kisabariman Limbangan dan MTs Al Hikmah Singorojo.

Adapun output dari kegiatan sosialisasi ini adalah untuk memberikan gambaran program sekaligus meminta izin ke Ketua Sub Rayon SMP/MTs wilayah Boja sekaligus konfirmasi terkait (1) tanggal pelatihan dan (2) Sekolah dan Madrasah sasaran yang akan menjadi peserta pelatihan.

Kedua, Pelatihan. Pelatihan ini dilakukan untuk memberdayakan para pendidik agar mampu mengenali dan mengaplikasikan sistem fonik bahasa Inggris. Fonik Bahasa Inggris lebih menekankan pada pelajaran alfabet yang diberikan terlebih dulu kepada anak-anak, mempelajari nama-nama huruf dan bunyinya. Pelatihan ini juga bertujuan agar guru-guru bahasa Inggris di lingkungan SMP dan MTs di Sub Rayon wilayah Boja, Kendal mampu membekali para peserta teentang pengajaran Bahasa Inggris berbasis phonics. Setelah mengikuti kegiatan ini diharapkan guru-guru pengampu mata pelajaran Bahasa Inggris memiliki pengetahuan pengajaran bahasa Inggris khususnya pada kemampuan pengucapan kata (pronunciation) berbasis pengajaraan Fonik.

Pelatihan "Pemberdayaan Guru Bahasa Inggris dengan metode fonik di Sub Rayon SMP/MTs Wilayah Boja Kabupaten Kendal" dilakukan di Aula SMPN 1 Boja, Kendal. Pelatihan ini dilaksanakan pada tanggal 25 Mei 2016. Narasumber untuk pelatihan ini adalah Agus Prayogo, M.Pd yang memberikan pelatihan dan implementasi program tentang Dinamikapembelajaran bahasa asing, Pengajaran bahasa asing dengan metode fonik, serta memandu peserta untuk pelaksanaan model implementasi, refleksi dan rencana tindak lanjut. Dra. Nuna Mustikawati Dewi (dosen PBI FITK UIN Walisongo) yang memberikan materi pelatihan tentang mengenal karakteristik siswa dan Proses pemerolehan Bahasa pada anak didik.

Kegiatan Pelatihan ini disampaikan pada para guru pengampu mata pelajaran Bahasa Inggris di Sub Rayon SMP/MTs wilayah Boja, Kendal. Masingmasing sekolah dan madrasah mengirimkan 2 orang guru untuk mengikuti pelatihan ini. Sebanyak 12 orang guru yang mengikuti kegiatan pelatihan ini. Hasil atau output pelaksanaan Pelatihan ini adalah para guru memiliki pengetahuan dan ketrampilan tentang English Phonics sebagai strategi pengajaran Bahasa Inggris terutama untuk pengajaran Speaking Skill. 
Ketiga, Pendampingan. Pendidikan dan pelatihan merupakan usaha untuk meningkatkan sumber daya manusia (SDM). Pelatihan berarti menuntun dan mengarahkan perkembangan dari peserta pelatihan melalui pengetahuan, keahlian dan sikap yang diperoleh untuk memenuhi standar tertentu. Dalam sebuah struktur pelatihan yang baik, tentunya terdapat tindak lanjut pasca diselesaikannya pelatihan. Ada beberapa kegiatan yang dapat dilakukan pasca pelatihan, salah satunya adalah dengan pendampingan sebagai tindak lanjut.

Kegiatan tindak lanjut itu bermakna strategis, sebab kegiatan tersebut menjamin penerapan hasil pelatihan sebagai sesuatu yang mesti berkelanjutan. Kegiatan tindak lanjut yang berupa pendampingan bertujuan untuk menguatkan penerapan hasil pelatihan dalam proses pembelajaran yang sudah dilakukan. Kegiatan pendampingan sama pentingnya dengan pelatihan guru. Dengan pendampingan guru sebagai agen pembaharu dari paradigma pendidikan benarbenar diwujudkan. Bagi fasilitator proses pendampingan merupakan alat ukur melihat keberhasilan dimana peserta sebagai guru dapat mengimplementasikan langsung di dalam kelas dan sekolahnya. Sekolah yang mengirimkan guru sebagai peserta pelatihan akan terjadi perubahan yang signifikan bagi pembelajaran di sekolah tersebut. Perubahan pembelajaran dikelas dan sekolah akan mendorong kondisi perubahan tingkah laku pembelajaran.

Dalam kegiatan pendampingan, para pendamping harus memahami peran sebagai fasilitator dan tidak menjadi supervisor. Dalam kegiatan pendampingan yang dilakukan sesuai dengan peranannya, maka para pendamping dan guru yang akan didampingi akan menimbulkan kemitraan yang baik yang akan mendorong tercapainya tujuan meningkatkan pembelajaran.

Kegiatan Pelatihan ini bertujuan untuk membekali para peserta tentang pengajaran Bahasa Inggris berbasis phonics. Setelah mengikuti kegiatan ini diharapkan guru-guru pengampu mata pelajaran Bahasa Inggris di Sub Rayon SMP/MTs Wilayah Boja memiliki pengetahuan pengajaran bahasa Inggris khususnya pada kemampuan pengucapan kata (pronunciation) berbasis pengajaraan Fonik.

Pada pelaksanaan program pendampingan ini, dua nara sumbernya yaitu Lulut Widyaningrum, M.Pd, (Dosen PBI FITK UIN Walisongo) dan Agus Prayogo, M.Pd (Dosen PBI FITK UIN Walisongo) yang akan memberikan pendampingan pelatihan dan implementasi program yang telah diikuti. Para pendamping bertugas untuk melakukan observasi implementasi program dengan seksama yang kemudian melakukan evaluasi bersama dengan guru yang didampingi. Kegiatan evaluasi menjadi bagian yang sangat penting untuk 
dilaksanakan untuk mengukur keberhasilan program sekaligus membuat perbaikan bila diperlukan.

Peserta kegiatan pendampingan pada program Pengabdian pada Masyarakat ini adalah para Guru pengampu mata pelajaran Bahasa Inggris di Sekolah dan Madrasah di Sub Rayon SMP/MTs wilayah Boja, Kendal. Terdapat 10 guru SMP dan Madrasah Tsanawiyah untuk didampingi yang berasal dari SMPN 1 Boja, SMPN 2 Boja, SMPN 3 Boja, MTs NU 11 Kisabariman Limbangan, MTs Al Hikmah Singorojo. Pelaksanaan Pendampingan program Pengabdian pada Masyarakat ini bertujuan untuk mendampingi para guru dalam meng-implementasikan metode fonik. Pelaksanaan pendampingan program pengabdian pada masyarakat ini dilaksanakan di masing-masing sekolah dan madrasah dampingan dengan jadwal menyesuaikan jadwal dimasing-masing sekolah dan madrasah. Adapun detail dari pendampingan di tiap-tiap sekolah adalah sebagai berikut:

\section{SMP N 1 Boja}

SMPN 1 Boja melakukan implementasi pembelajaran pengenalan bunyi bahasa Inggris dengan metode fonik pada materi kegiatan yang disukai terkait hal-hal yang berhubungan dengan makanan, minuman, dan olah raga. Pada kegiatan ini, siswa mempraktekan percakapan dengan topik like and dislike yang akan mengasah speaking skill mereka. Siswa diberi kebebasan untuk menentukan topik conversation yang mereka sukai. Hal ini dimaksudkan agar mereka lebih menguasai topik and memudahkan mereka untuk mengembangkan pembicaraan. Disini, guru memanfaatkan kartu yang berisi kosakata untuk membantu siswa mengucapkan kosakata tersebut secara tepat. Kartu tersebut akan bermanfaat untuk mengidentifikasi bunyi-bunyi dari kosakata yang diucapkan.

Pada pertemuan kali ini, guru menggunakan metode three phase technique untuk mengeksplore kemampuan siswa. Dengan kombinasi dua metode tadi, banyak siswa yang tepat menyebutkan kata-kata yang dimaksud meski masih dibutuhkan latihan dan pembiasaan.

Beberapa kendala/hambatan dalam pelaksanaan kegiatan ini adalah:

1. Para siswa tidak terbiasa fokus pada bunyi fonik dan pengucapan kata-kata tertentu sehingga diperlukan pembiasaan.

2. Porsi speaking tidak banyak dibandingkan dengan skill yang lain seperti menulis dan membaca.

3. Sistem fonik tidak hanya terdapat pada topik speaking. 
4. Jumlah jam yang tersedia tidak memberikan kesempatan untuk lebih fokus pada fonik.

5. Jumlah materi yang harus diselesaikan tidak seimbang dengan waktu yang ada khususnya yang fokus pada pembelajaran fonik.

\section{SMP N 2 Boja}

SMPN 2 Boja melakukan implementasi pembelajaran fonik pada materi report text pada kegiatan yang terkait hal-hal yang berhubungan dengan pengumuman dan iklan. Pada kegiatan ini, siswa mempraktekan monolog pendek yang akan mengasah speaking skill mereka. Disini, guru mengajarkan fonik fokus pada kosakata yang kurang tepat diucapkan oleh siswa. Dalam mengoreksi pronunciation siswa, guru menggunakan bantuan Kartu yang berisi alfabet dan menggabungkannya agar bisa berbunyi. Praktek seperti ini akan melatih dan membiasakan siswa untuk mengenali bunyi-bunyi khususnya dalam bahasa Inggris. Sebagai variasi, guru menggunakan "jumbled letters" dengan cara memberikan tiga buah kartu atau lebih yang berisi huruf yang berbeda-beda kepada siswa kemudian meminta siswa untuk menyusunnya dan mengucapkannya.

Pada pertemuan kali ini, guru sebenarnya lebih memfokuskan pada teks report sebagai materi utama dengan menggunakan metode role play dan drilling untuk mengeksplore kemampuan siswa. Adapun fonik bahasa Inggris dijadikan penunjang pratek dan kemampuan berbahasa siswa.

Beberapa kendala/hambatan dalam kegiatan ini adalah:

1. Porsi speaking tidak banyak dibandingkan dengan skill yang lain seperti menulis dan membaca.

2. Diperlukan kejelian guru untuk memasukkan materi fonik karen sistem fonik selalu dianggap hanya terdapat pada topik speaking.

3. Jumlah jam yang tersedia tidak memberikan kesempatan untuk lebih fokus pada fonik. Jumlah materi yang harus diselesaikan tidak seimbang dengan waktu yang ada khususnya yang fokus pada pembelajaran fonik.

4. Perlu persiapan khusus mempersiapkan kartu fonik yang cukup menyita waktu.

\section{SMP N 3 Boja}

SMPN 3 Boja melakukan implementasi metode fonik pada materi kegiatan membaca. Disini, siswa diberi kumpulan kata-kata sederhana yang kemudian dapat diubah menjadi frasa dan kalimat. Prinsipnya, kata atau 
kalimat tadi tetap diucapkan sesuai dengan bunyi yang seharusnya dan menggunakan prinsip bunyi yang ada di sistem fonik. Guru akan memberikan koreksi sekaligus contoh pengucapan untuk kata-kata yang dianggap sulit. Metode ini membantu siswa dalam mengenali bunyi fonik dalam bahasa Inggris sehingga siswa lebih fokus dan tahu apa yang harus diucapkan.

Pada pertemuan kali ini, guru menggunakan metode drilling dengan meminta siswa membaca berulang-ulang dan membetulkan yang salah. Ketika guru memperhatikan dengan seksama, ternyata banyak siswa yang tepat menyebutkan kata-kata yang dimaksud.

Beberapa kendala/hambatan dalam kegiatan ini adalah:

1. Para siswa perlu pembiasaan berulang-ulang yang cukup menyita waktu yang berimbas pada pemahaman bacaan siswa. Mereka menjadi lebih fokus pada pengucapan daripada isi dari bacaan.

2. Jumlah jam yang tersedia tidak memberikan kesempatan untuk lebih fokus pada fonik. Hal ini karena guru merasa fonik harus diajarkan tersendiri agar kompetensi materi yang diajarkan dapat dicapai.

3. Jumlah materi yang harus diselesaikan tidak seimbang dengan waktu yang ada khususnya yang fokus pada pembelajaran fonik.

\section{MTs NU 11 Kisabariman Limbangan}

MTs $\mathrm{Nu} 11$ Kisabariman Limbangan mengimplementasikan pembelajaran dengan menggunakan label fonik. Cara ini bertujuan untuk membiasakan siswa dengan bunyi-bunyi huruf yang ternyata banyak terdapat dibunyi awal benda-benda disekelilingnya. Untuk cara ini menggunakan peralatan seperti kartu, spidol, dan silotip. Dalam mempraktekan strategi ini, guru menempelkan huruf ke benda di rumah yang berawalan dengan huruf yang sudah familiar dan dipelajari. Siswa menyebutkan bunyi huruf dan nama benda setiap kali melewati/ melihatnya. Namun, ada hal yang harus diperhatikan disini yaitu untuk tidak memberikan label kepada benda yang bunyinya berbeda dengan bunyi yang baru dipelajari.

Pada pertemuan kali ini, guru dapat mengeksplore kemampuan siswa dengan strategi ini. Dengan latihan berulang-ulang, banyak siswa yang mampu dengan tepat menyebutkan kata-kata yang dimaksud.

Beberapa kendala/hambatan dalam kegiatan ini adalah: 
1. Siswa mempunyai kemampuan bahasa yang agak rendah dan mereka tidak terbiasa fokus pada sistem fonik sehingga diperlukan pembiasaan.

2. Porsi speaking tidak banyak dibandingkan dengan skill yang lain seperti menulis dan membaca.

3. Sistem fonik tidak hanya terdapat pada topik speaking.

4. Jumlah jam yang tersedia tidak memberikan kesempatan untuk lebih fokus pada fonik.

5. Jumlah materi yang harus diselesaikan tidak seimbang dengan waktu yang ada khususnya yang fokus pada pembelajaran fonik.

6. Kompetensi guru kurang karena belum menyelesaikan pendidikan strata satunya.

\section{MTs Al Hikmah Singorojo}

MTs Al Hikmah Singorojo melakukan implementasi pembelajaran EPS dengan menggunakan teknik Asosiasi fonemik dengan berbantu kartu alfabet. Teknik ini berfungsi menumbuhkan kepekaan terhadap bunyi, dengan mencari persamaan bunyi huruf yang dipelajari dengan bunyi di alam sekitar. Misalnya bunyi "be" dikaitkan dengan bunyi suara motor vespa, "be-be-be-be.." bunyi "i”" dikaitkan dengan rasa geli melihat cacing, "iiiii..." Disini, guru memanfaatkan kartu yang berisi kosakata untuk membantu siswa mengucapkan kosakata tersebut secara tepat. Kartu tersebut akan bermanfaat untuk mengidentifikasi bunyi-bunyi dari kosakata yang diucapkan.

Pada pertemuan kali ini, guru menggunakan metode drilling dan role play untuk mengeksplore kemampuan siswa. Dengan pengenalan seperti ini, banyak siswa yang tepat menyebutkan kata-kata yang dimaksud. Selain itu, ada beberapa manfaat yang diperoleh dari kegiatan ini yaitu siswa menjadi lebih aktif dan suasana kelas menjadi lebih hidup dan tidak membosankan.

Beberapa kendala/hambatan dalam kegiatan ini adalah:

1. Para siswa tidak terbiasa fokus pada sistem fonik sehingga diperlukan pembiasaan.

2. Porsi speaking tidak banyak dibandingkan dengan skill yang lain seperti menulis dan membaca.

3. Sistem fonik ada pada skill membaca dan tidak hanya terdapat pada topik speaking. 
4. Jumlah jam yang tersedia tidak memberikan kesempatan untuk lebih fokus pada fonik.

5. Jumlah materi yang harus diselesaikan tidak seimbang dengan waktu yang ada khususnya yang fokus pada pembelajaran fonik.

\section{KESIMPULAN}

Kegiatan implementasi metode fonik dilaksanakan ditiap sekolah dan madrasah dampingan dengan disain program sosialisasi, pelatihan dan pendampingan. Hampir semua sekolah sudah mampu mengimplementasikan strategi fonik yang diperkenalkan dalam latihan mulai dari penggunaan teknik phonic label, asosiasi fonemik hingga membaca kata dan frasa yang berbantu kartu alfabet. Pendampingan dilaksanakan untuk mengawal pelaksanaan dan juga untuk memberikan penguatan kepada seluruh guru untuk melanjutkan program pembelajaran dengan metode fonik ini. Guru-guru sangat diharapkan menjaga komitmen mereka untuk memperhatikan dan membimbing siswa secara telaten. Improvisasi terhadap teknik dan media ajar sangat dianjurkan untuk menjembatani rasa bosan dalam proses pembelajaran di kelas.

\section{DAFTAR PUSTAKA}

Chaer, Abdul. 2007. Linguistik. Umum. Jakarta: Rineka Cipta

Clark, M.2013. Is there one best method of teaching reading? What is the efidence? Educational Journal. Issue 156: 14-16.

National Reading Panel (NRP). (2004). Teaching cbildren to read: An evidence-based assessment of the scientific research literature on reading and its implications for reading instruction. Washington, DC: National Academy Press.

Phajane, M. H. 2014. Introducing Beginning Reading Using Phonics Approach.
Mediterranean Jounal of Social Sciences. 05/10: 477-483 Doi:10.5901/mjss.2014.v5n10p477

Roach, Peter. 1998. English Phonetics and Phonology. Cambridge: Cambridge University Press.

Serna, C.S. 2006. The Role of Phonemic Awareness and Phonics in Beginning Reading. Journal of Adventist Education. April/May 
Wlandari, R.O. 2012. Meningkatkan Kemampuan Mengenal Huruf Melalui Metode Fonik Bagi Anak Tunarungu Sedang. E-Jurnal Pendidikan Khusus. I (2): 358-369 